\title{
An exceptional surface occurrence: the middle to upper Miocene succession of Pécs-Danitzpuszta (SW Hungary)
}

\author{
SEBE, Krisztina ${ }^{1}$, KonRÁD, Gyula ${ }^{1}$, SzTANó, Orsolya ${ }^{2}$ \\ ${ }^{1}$ University of Pécs, Department of Geology and Meteorology, 7624 Pécs, Ifjúság útja 6., Hungary; \\ sebe@gamma.ttk.pte.hu; konradgyula@t-email.hu \\ ${ }^{2}$ ELTE Eötvös Loránd University, Institute of Geography and Earth Sciences, Department of Geology, 1117 Budapest, Pázmány Péter sétány 1/c; \\ orsolya.sztano@ttk.elte.hu
}

\section{Egy kivételes feltárás: a pécs-danitzpusztai homokbánya középső-felső miocén rétegsora}

Összefoglalás

A pécs-danitzpusztai homokbánya az idős pannóniai (felső miocén) üledékek legfontosabb feltárása Magyarország déli felén. 2018-ban árkolás tárta fel az ismert pannon-tavi összlet feküjét egészen a felső badeniig, ezzel mintegy $220 \mathrm{~m}$ valódi vastagságban folyamatos rétegsor lett hozzáférhető. Szerkezeti mozgások hatására a középső miocén üledékek és a pannóniai mészmárga nagy része átbuktatott, a mészmárga-homok határ környéke függóleges, majd a pannóniai homokban folyamatosan csökken a rétegdőlés. A feltárt rétegsor $5 \mathrm{~m}$ felső badeni (valamikor 13,8-12,6 millió év között lerakódott) mészmárgával és homokos mészkővel (Lajtai Mészkő) kezdődik, amely a Középsô-Paratethys normál sótartalmú vizében halmozódott fel, és szublitorális, majd litorális környezetet jelzô puhatestúeket tartalmaz. Ezt 8 m vastag, túlnyomórészt ősmaradványmentes homok, kőzetliszt és kavics követi, melynek kora bizonytalan, csak a legalsó aleuritréteg tartalmaz feltehetőleg áthalmozott badeni mikrofaunát. Ez az egység szárazföldi hordalékkúpon vagy annak vízbe nyúló alsó részén rakódhatott le gravitációs üledékfolyásokból. A rákövetkező 7,5 m vastag, mészkő, márga és agyag vékony rétegeinek váltakozásából álló szakasz szublitorális ősmaradványokat tartalmaz, gyors elöntésre utalva. A benne található foraminiferák, ostracodák, puhatestúek és mészvázú nannoplankton alapján az üledéklerakódás a késő szarmatában (valamikor 12,1 és 11,6 millió év között, Kozárdi Formáció), a brakkvízú Paratethysben történt, majd a pannóniai elején folytatódott. Az egyes ôsmaradványcsoportok által jelzett határok ugyanakkor nem esnek egybe. A szarmata vége felé néhány rétegben időszakosan csökkent a sótartalom, valószínúleg édesvíz-beáramlás miatt. A pannóniaiban fölfelé a mészmárga válik uralkodóvá, amelybe agyag-, valamint gradált vagy szerkezet nélküli kavics és homok(kő) rétegek települnek. Ezek a kőzetek nyílt, valószínúleg több száz méter mély vízben rakódtak le. Az összesen 64 m vastag mészmárga sorozat a Pannon-medencében fúrások ezreiből ismert Endrődi Formáció ritka, jól feltárt felszíni előfordulását képviseli. A következő 6-7 m vastag, kőzetlisztes márgából és homokból álló átmeneti szakasszal együtt a pannóniai korai szakaszában, kb. 11,62 és 10,2 Ma közt keletkezett. Ezután kb. 140 m vastag limonitos, kavicsos homok következik, amely a Békési Formáció Kállai Tagozatával rokonítható. Osztályozottsága és a szemcsék koptatottsága jellemzően gyenge vagy közepes, rétegei méteres vastagságúak, szerkezetmentesek, határukat leginkább a cementáció és a mállás változása mutatja. Nagy mennyiségú, idősebb miocén összletekből áthalmozott ősmaradványt és kavicsot, valamint valószínúleg sekélyebb vízből származó pannóniai fosszíliákat tartalmaz. Kb. 10,2 és 10,0 Ma közt rakódhatott le durva hordalékú delták gravitációs üledékfolyások által táplált mélyvízi alsó részén.

Kulcsszavak: Pannon-tó, Paratethys, Mecsek, badeni, szarmata, pannóniai, Endródi Formáció

Abstract

The Pécs-Danitzpuszta sand pit is the most important outcrop of the oldest Pannonian (upper Miocene, Tortonian) deposits in southern Hungary. A trench excavated in 2018 exposed Lake Pannon deposits and underlying Paratethys strata down to the upper Badenian (Serravallian), and together with the sand pit they make up a continuous sedimentary succession with a true thickness of $\sim 220 \mathrm{~m}$. Due to tectonic deformation, middle Miocene deposits and carbonates in the lowermost Pannonian are overturned. Layers become vertical close to the marl-sand boundary, then the dip changes to normal, with continuously decreasing dip angles. The exposed succession starts with $5 \mathrm{~m}$ of upper Badenian (13.8-12.6 Ma old) calcareous marls and sandy limestones with sublittoral, then littoral mollusks, which were deposited in the normal salinity seawater of the Central Paratethys. The overlying $8 \mathrm{~m}$ of sand, silt, sandy breccia and conglomerate are fossil-free; only the lowermost silt layer contains reworked Badenian microfauna. This unit probably accumulated from gravity-driven flows in a fan-like, presumably terrestrial depositional setting. The next $7.5 \mathrm{~m}$ of frequently alternating thin-bedded limestones, marls and clays with sublittoral biota represent rapid transgression. Foraminifers, ostracods, mollusks and cal- 
careous nannoplankton indicate late Sarmatian, then Pannonian age for this interval. However, the locations of the boundaries indicated by the various groups are not consistent, making the position of the Sarmatian/Pannonian boundary uncertain. The Sarmatian beds with marine fossils still accumulated in the Paratethys, between $~ 12.1-11.6 \mathrm{Ma}$, under varying salinities due among others to temporary freshwater input. The Pannonian strata already represent sediments of the brackish Lake Pannon. Above these beds, uniform calcareous marl becomes dominant with some clay layers and graded or structureless conglomerate to sandstone interbeds. The deposition of the overall $64 \mathrm{~m}$ thick Pannonian calcareous marl section took place in the open, probably few hundred metres deep water of the lake. It may represent a rare, wellexposed surface occurrence of the Endrőd Formation, which is known from thousands of wells in the Pannonian Basin. Together with the overlying 6-7 m thick transitional interval of silty marls and sands they were deposited between $\sim 11.62$ and 10.2 Ma. They are followed by $\sim 140 \mathrm{~m}$ of limonitic, pebbly sands. The sands have poor to moderate sorting and rounding, metre-thick beds with transitional boundaries and abundant fossils and clasts reworked from older Miocene units. Their accumulation may have occurred between 10.2 and 10,0 Ma by gravity flows connected to deep-water portions of fan deltas.

Keywords: Lake Pannon, Paratethys, Mecsek Mts, Badenian, Sarmatian, Pannonian, Endröd Formation

\section{Introduction}

In southern Hungary sediments from the early phase of the late Miocene Lake Pannon and the preceding middle Miocene Paratethys sea crop out only in the Mecsek Mts. The Pécs-Danitzpuszta sand pit along the SE margin of the mountains is the most important and best-known outcrop of the oldest Pannonian (upper Miocene, Tortonian) deposits, dominated by calcareous marls and limonitic sands. It has long been known for the deformations visible in the sands (VADÁSZ 1960), and is a type locality of Lake Pannon sediments in the Mecsek area (KLEB 1973). The sand pit is a well-known fossil site as well, with abundant vertebrate remains in the sands, including fishes, amphibians, reptiles as well as terrestrial and marine mammals (KAZÁR et al. 2007, KONRÁD et al. 2010a, SEBE et al. 2015, SZENTESI et al. 2020, SZABÓ et al. 2021). Since the 1990s intense excavation created newer and newer outcrop profiles. By now works have reached the edge of the concession area and sand extraction is nearing its end. Thanks to the support of the mining company with excavating a trench for research purposes in the northern margin of the sand pit in 2018 , it was possible to significantly extend our knowledge on the Miocene evolution of the area. The trench not only reached the base of the upper Miocene succession, but also exposed the underlying middle Miocene units.

Here we present the observations gathered during the past decades on the sedimentary succession exposed by the sand pit and the trench. Investigations focused on lithology and stratigraphy, with the aim of describing the building blocks of the succession, constraining their depositional environment and the factors influencing sedimentation.

\section{Geological setting}

The Pécs-Danitzpuszta sand pit lies on the eastern edge of the city of Pécs, at the foot of the Mecsek Mts (Figure 1). Its largest dimensions are approximately $700 \mathrm{~m}$ in W-E and $400 \mathrm{~m}$ in N-S direction, the latter being roughly parallel with the dip of the succession (Figure 2). Deposits crop out mostly along the western and northern walls. The sand pit itself exposes two main lithological units of late Miocene (Panno- nian) age: light grey, white or yellowish grey calcareous marls and silts in the northern wall, and the overlying yellowish brown, coarse, limonitic sands in the rest of the area. The mountains directly north of the sand pit are built up of Mesozoic rocks, mostly Lower Jurassic marls and sandstones, which are overlain by lower Miocene terrestrial gravels and sands and middle Miocene marine clastics and carbonates (Figure 1C). In the detailed geological map of the area, Pannonian sediments are indicated to have a tectonic contact with the middle Miocene strata north of them (HÁMOR et al. 1966).

The locality lies along a fault zone that borders the Mecsek Mts in the south (Mecsekalja Fault Zone). The exposed succession bears signs of syn-sedimentary deformation (KLEB 1973) and has undergone at least two phases of tectonic deformation related to the activity of this fault zone (KONRÁD \& Sebe 2010, Sebe 2021). Syn-sedimentary normal faults and negative flower structures in the lower part of the sand indicate coeval transtension. Tilting and even overturning of the succession from the Badenian beds to the lowermost, faulted Pannonian sand beds refers to strong compression in a later phase. This deformation still occurred during the accumulation of the sand, as shown by the gradual upward decrease of the dip angle. An angular unconformity produced by this event within the sands (Figure $2 B$ ) was also documented in earlier publications (e.g., BARTHA 1971, KLEB 1973). As a result of the tilting, younging is dominantly towards the south (Figure $2 B$ ). Early Pannonian compression is probably related to AdriaEurope convergence; however, this event cannot be correlated regionally, it pre-dates basin inversion-related events reported from the region (Sebe 2021, Sebe \& Magyar submitted).

\footnotetext{
$\rightarrow$ Figure 1. Geological setting of the Pécs-Danitzpuszta sand pit. A) Site location relative to the reconstructed outlines of Lake Pannon at $10.8 \mathrm{Ma}$ (from MAGYAR et al. 1999), overlain on the background of modern topography. B) Geological map of the area surrounding the sand pit (modified from CHIKÁN \& BUDAI 2005). Legend: T: Triassic; J: Jurassic; M1-2: lower-middle Miocene; M3: upper Miocene rocks; MFZ: Mecsekalja Fault Zone. C) Miocene lithostratigraphic units of the Mecsek region

$\rightarrow$ 1. ábra. A pécs-danitzpusztai homokbánya földtani környezete. A) A feltárás helyzete a Pannon-tó 10,8 millió évvel ezelötti kiterjedéséhez képest. A tó körvonala MAGYAR et al. (1999) alapján. B) A szükebb környék földtani térképe (CHIKÁN \& BUDAI 2005 alapján módositva). T: triász; J: jura; M1-2: alsó-középsö miocén; M3: felsö miocén (pannóniai) kőzetek; MFZ: Mecsekalja-vetözóna. C) A Mecsek és környezete miocén litosztratigráfiai egységei
} 

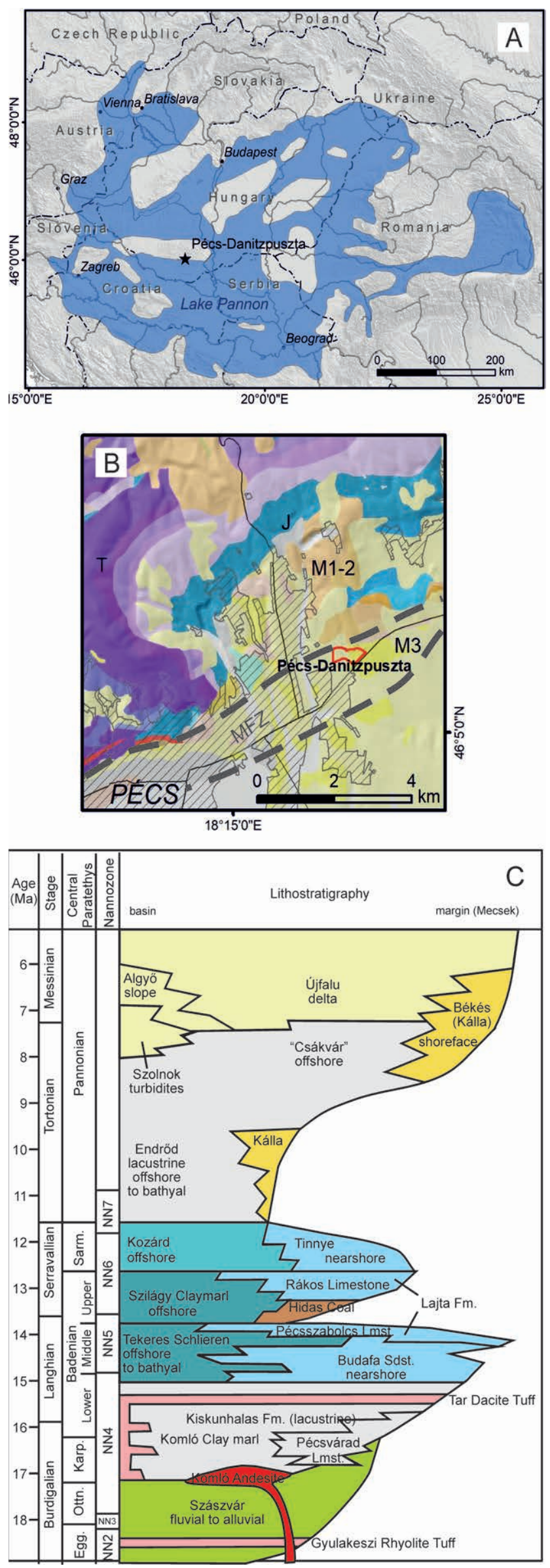
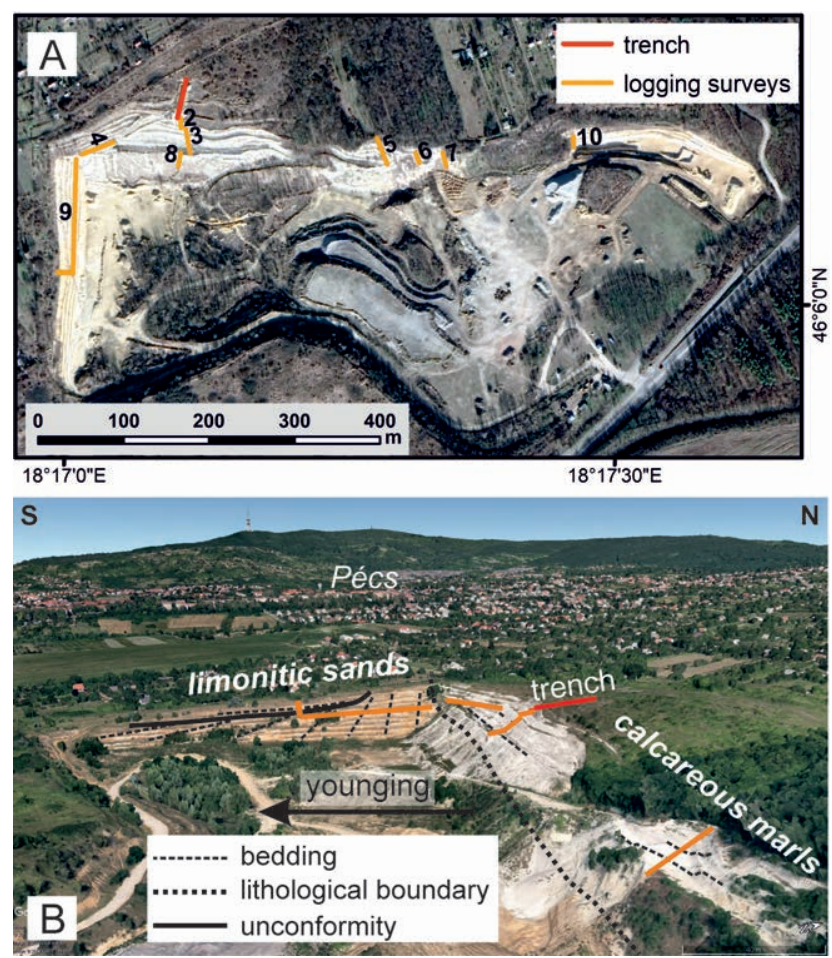

Figure 2. Location of sedimentary sections. A) Map view on an aerial photo from 2004; B) oblique satellite view from the east (image from GoogleEarth, 2019)

2. ábra. A rétegsorfelvételek helye A) térképi nézetben, 2004-es légifelvételen és B) kelet felöl, ferdén letekintve (GoogleEarth müholdkép, 2019)

\section{Methods}

The deposits and structural features were documented from time to time as the industrial excavation progressed. The sedimentary succession was recorded in multiple logs from the best-exposed sites at the given time (Figure 2). The profiles presented in the current paper were selected to cover the entire succession exposed in the sand pit. The trench excavated in September 2018 (Figure 3) was $50 \mathrm{~m}$ long, elongated NNE-SSW and extended the stratigraphic column downward by a true thickness of $37 \mathrm{~m}$.

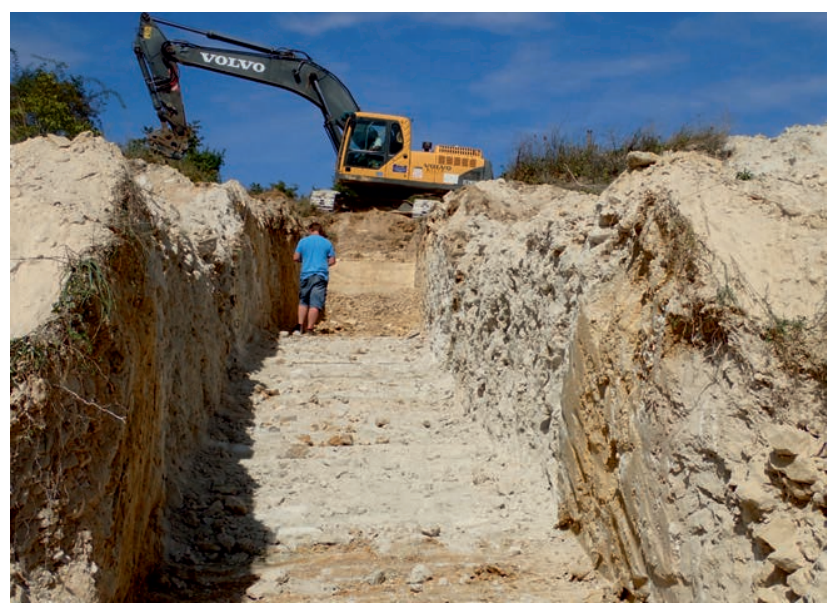

Figure 3. Excavation of the trench in September 2018 at the northern margin of the sand pit

3. ábra. Az árok mélyitése a bánya északi oldalán, 2018 szeptemberében 

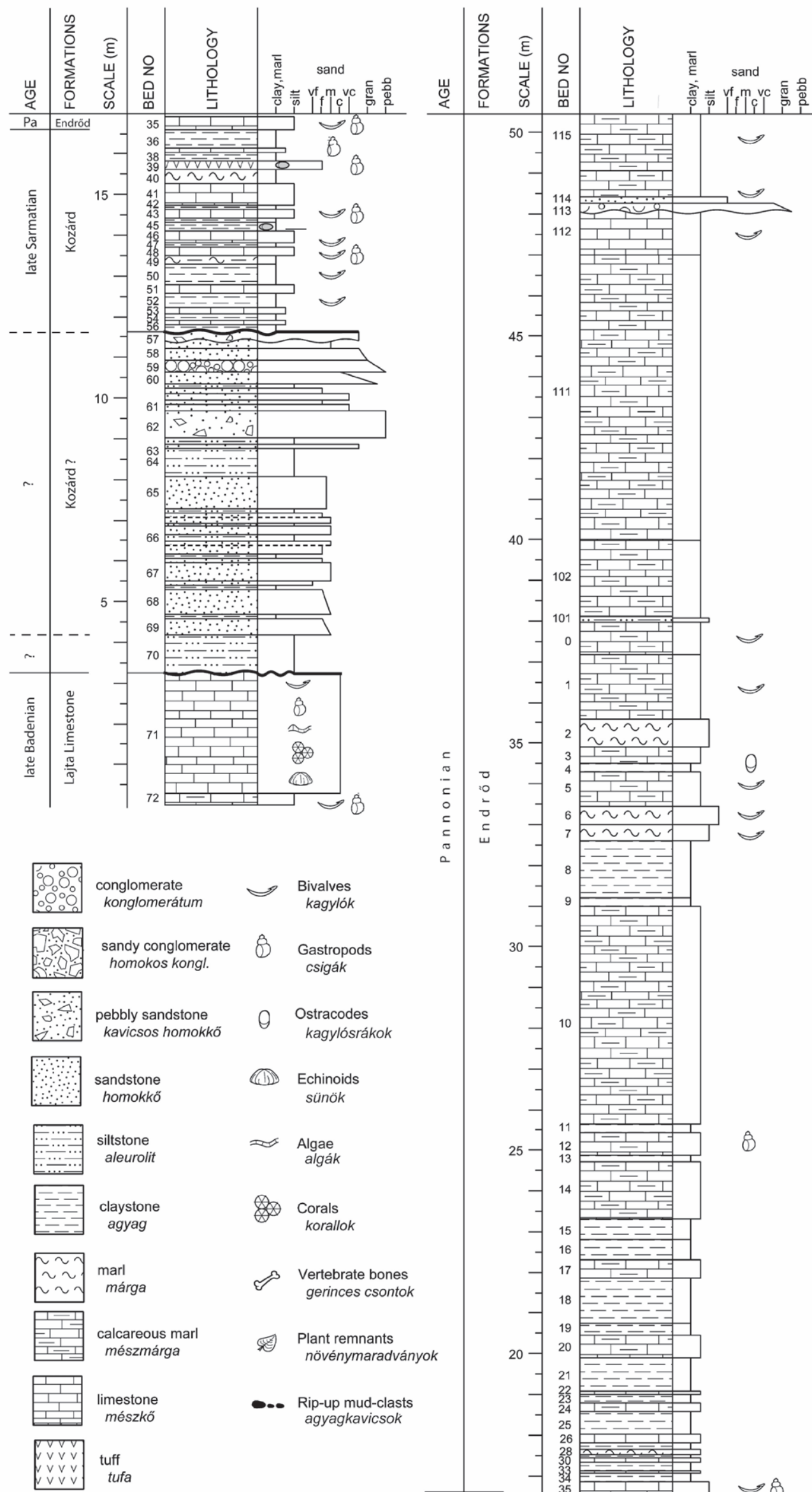
iflic o 

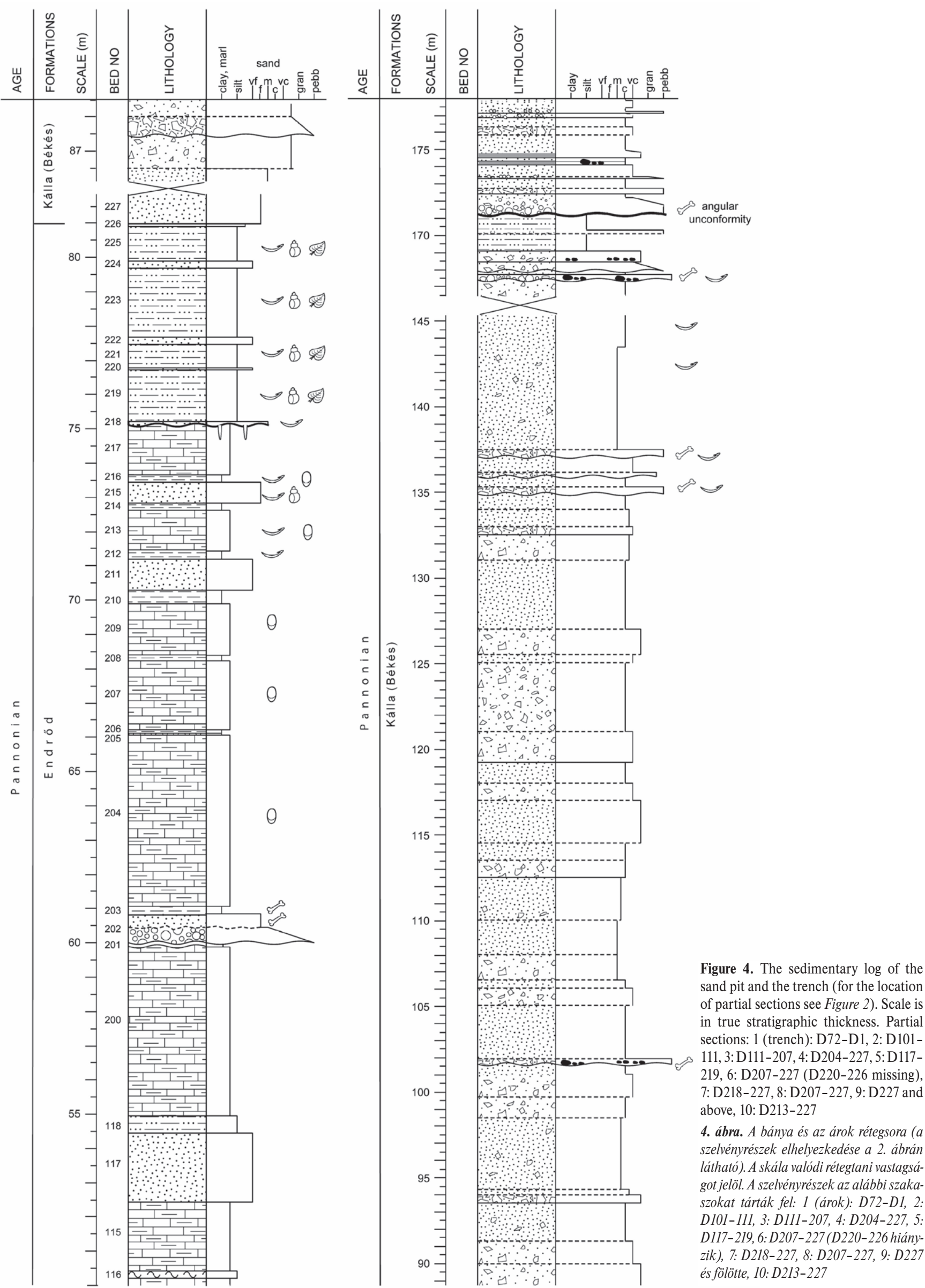
sand pit and the trench (for the location of partial sections see Figure 2). Scale is in true stratigraphic thickness. Partial sections: 1 (trench): D72-D1, 2: D101219, 6: D207-227 (D220-226 missing), : 227 and

4. ábra. A bánya és az árok rétegsora (a szelvényrészek elhelyezkedése a 2. ábrán látható). A skála valódi rétegtani vastagságot jelöl. A szelvényrészek az alábbi szakaszokat tárták fel: 1 (árok): D72-D1, 2: D101-111, 3: D111-207, 4: D204-227, 5: D117-219, 6:D207-227(D220-226 hiányzik), 7: D218-227, 8: D207-227, 9: D227 és fölötte, 10: D213-227 
During the documentation of the sedimentary succession standard field observations were carried out. Lithology, grain size, thickness, types of bedding contacts, sedimentary structures and macrofossil content were recorded with $\mathrm{cm}$-scale accuracy. Since logging was only possible in parts of the succession at a given time, bed numbers of the sedimentary succession are not consecutive and contain gaps, and span from D72 (lowermost Badenian layer) to D227 (start of the limonitic sands). When stratigraphically overlapping sections were logged, some beds occurred in one section and were missing in others. Nevertheless, it was possible to follow several important beds (e.g., tuff, clay with carbonate concretions, clay-sand-clay triplet) for hundreds of metres along the northern wall, allowing us to fit the puzzle pieces of the sedimentary column together.

Systematic sampling was carried out from 83 layers for palynological, nannoplankton, ostracod, foraminifer and mollusc studies (Figure 4). Detailed results of the specific investigations are presented in the other papers of this journal volume (BotKa et al. 2021, CsOMA et al. 2021, ĆORIĆ 2021, Dulai et al. 2021, KrizManiĆ et al. 2021, SZABÓ et al. 2021, SZUROMI-KoRECZ et al. 2021). In addition, samples were taken for petrographic investigations, authigenic ${ }^{10} \mathrm{Be} /{ }^{9} \mathrm{Be}$-isotope dating, and multiple radiometric dating methods from an upper Miocene tuff layer. Their analysis is underway, therefore they will not yet be discussed here.

\section{Sedimentary succession}

A continuous sedimentary succession with a true thickness of $\sim 220 \mathrm{~m}$ was documented in the trench and the sand pit (Figure 4). Sediments from the bottom of the succession to the top of the Pannonian marls were $80 \mathrm{~m}$ thick. The overlying Pannonian limonitic pebbly sands reached a thickness of about $140 \mathrm{~m}$, of which the lower $\sim 60 \mathrm{~m}$ plus the succes- sion above the unconformity were logged in detail, where exposure allowed to take a continuous record. The further $\sim 70 \mathrm{~m}$ below the unconformity were covered to a large extent during the logging, but point-like observations showed that lithology did not change significantly in this interval. The observed sedimentary facies are listed in Table 1.

The oldest part of the succession was exposed in the exploratory trench (Figure 5). Due to tectonic deformation, most of this interval is overturned, and the stratigraphically lowest (oldest) layers are located in the north. Overturned beds become steeper towards the south (upsection) until they are vertical close to the southern end of the trench. From there on, they change to normal but steep, southerly dips.

This section describes the main lithological and sedimentological features of the succession, from bottom to top, subdivided into intervals of similar lithologies. The paleontological data justifying the age of the intervals and their lithostratigraphic classification are presented in the discussion section and the papers cited there. The ages of the distinguished sedimentary units provided by biostratigraphic investigations are also used in the titles of the coming sections to help the orientation of the reader.

\section{Badenian marl, bioclastic limestone (D72-71)}

The lowermost exposed sediments, up to a thickness of $2 \mathrm{~m}$, are yellowish white, fossiliferous limestone and calcareous marl with a thickness of $2 \mathrm{~m}$, hosting abundant mollusk shells and imprints including Rissoa, Venus and Myrtea species (Dulai et al. 2021). They are overlain by about $3 \mathrm{~m}$ of coarse bioclastic limestone, calcarenite with mollusk shells, shell fragments, remains of bryozoans and nodules of corallinacean algae (Figure 6A). The macrofauna is dominated by Cubitostrea shells (Dula et al. 2021). A shark tooth (cf. Araloselachus, SzABó et al. 2021) was found in the calcarenites as well. Bedding is not visible, the rock is rather

Table I. Sedimentary facies and interpretation from the outcrop

I. táblázat. A feltárt rétegsor litofáciesei és azok értelmezése

\begin{tabular}{|c|c|c|c|c|c|c|}
\hline Lithofacies & Grain size & Macrofossils & Bed contacts & $\begin{array}{l}\text { Bed } \\
\text { thickness } \\
(\mathrm{cm})\end{array}$ & Depositional processes & $\begin{array}{l}\text { Examples, bed } \\
\text { no., or metres }\end{array}$ \\
\hline \multicolumn{7}{|l|}{ Carbonates } \\
\hline coarse bioclastic limestone & - & $\begin{array}{l}\text { diverse marine } \\
\text { bivalves, corals, } \\
\text { corallinacean } \\
\text { algae }\end{array}$ & - & 1 & $\begin{array}{l}\text { biological, transported in } \\
\text { agitate waters }\end{array}$ & D71 \\
\hline $\begin{array}{l}\text { structureless microcrystalline } \\
\text { limestone }\end{array}$ & - & $\begin{array}{l}\text { ostracods, } \\
\text { bivalves, } \\
\text { gastropods }\end{array}$ & $\begin{array}{l}\text { sharp, slightly } \\
\text { irregular }\end{array}$ & $3-33$ & $\begin{array}{l}\text { plankton and benthic } \\
\text { biomass, quiet suspension } \\
\text { settling, bioturbation }\end{array}$ & $\begin{array}{l}\text { D55, D53, D48, } \\
\text { D46, D43, D41, } \\
\text { D37, D35, D33, } \\
\text { D30, } \\
\text { D26 }\end{array}$ \\
\hline $\begin{array}{l}\text { laminated microcrystalline } \\
\text { limestone }\end{array}$ & - & $\begin{array}{l}\text { gastropods, } \\
\text { bivalves }\end{array}$ & sharp, flat & 20 & $\begin{array}{l}\text { plankton and benthic } \\
\text { biomass, quiet suspension } \\
\text { settling, dysoxic bottom }\end{array}$ & D51, D48 \\
\hline gray, structureless, (clayey) marl & - & - & transitional & $20-35$ & $\begin{array}{l}\text { biogenic with terrigenous, } \\
\text { input, suspension settling }\end{array}$ & D49, D40, \\
\hline
\end{tabular}


Table I. continuation

I. táblázat. folytatás

Lithofacies mostly structurless, very hard or friable marl, calcareous marl

\section{Siliciclastics}

fossiliferous, greenish brown, gray or white structureless clay or silt, rare $\mathrm{Mn}$ nodules, rarely bentonitic gray or white, rarely laminated,

$\begin{array}{lll}\text { Grain size } & \text { Macrofossils } & \text { Bed co } \\ \text { - } & \begin{array}{l}\text { bivalves, } \\ \text { gastropods, rare } \\ \text { horizontal } \\ \text { winding burrows }\end{array} & \begin{array}{l}\text { transition } \\ \text { sharp }\end{array} \\ & & \\ & & \\ \text { clay, silty } & \text { bivalve shells, } \\ \text { clay, } & \text { gastropods, large } \\ \text { clayey silt } & \text { ostracods } & \end{array}$

clayey silt
Bed

thickness Depositional processes

(cm)

transitional or 3-100 dominantly biogenic

rate
Examples, bed no., or metres

D32, D28, D24,

D22, D20, D17,

D14, D12, D10,

D6-7, D3-0,

D101-

D56, D54, D52,

D50, D47, D45,

D42, D39, D38,

D36, D34, D31,

D25, D23, D21,

D18, D16-15,

D13, D11, D8-9,

D203, D210,

D212, D214,

D216; D219-

$225 ; 170 \mathrm{~m}$

D63, D64, D67-

69, D70

low-density gravity flows

(slurry flows)

some reworked

forams and

ostracods

vf-m* absent

structureless sandstone, rare

planar lamination, normal

gradation, alternates with gS or Fs,

polimictic composition

mostly structureless sand(stone), rare planar lamination, normal gradation, load structures; moderately to well sorted, quartzrich composition

poorly sorted, structureless granular, pebbly sand(stone), occasionally normal gradation, ratio

$\mathrm{m}-\mathrm{vc}$, granule, pebble

of gravel and pebble varies: $10-30 \%$

matrix-supported, poorly sorted, structureless, sandy breccia, nongraded with angular-subangular clast clast-supported conglomerate, c-vc sandy matrix, normal gradation

clast-supported mud-clast conglomerate, c-vc sandy matrix $\mathrm{m}-\mathrm{c}$, pebble

granule, pebble mostly absent, rare bivalves
10-200 transitional sharp or transitional

$10-60$

high-density sandy turbidity currents or grain flows

high-density sandy turbidity currents
D113-114, D117, D201202, D211, D215; D218, D220, D222; D224, D227 and above absent

mostly $10-400$

high-density gravelly D59-61 transitional, rarely sharp turbidity currents or grain flows

$87 \mathrm{~m}-145 \mathrm{~m}$

sharp

65

grain flow

D62 vertebrate

bones,

bivalves sharp,

erosional
10-100

\section{high-density gravelly \\ turbidity currents}

$87.5 \mathrm{~m}, 102 \mathrm{~m}$,

$135 \mathrm{~m}, 136 \mathrm{~m}$, $137 \mathrm{~m}, 168 \mathrm{~m}$, $172 \mathrm{~m}, 173.5 \mathrm{~m}$, $176 \mathrm{~m}$

$167.5 \mathrm{~m}, 169 \mathrm{~m}$ 


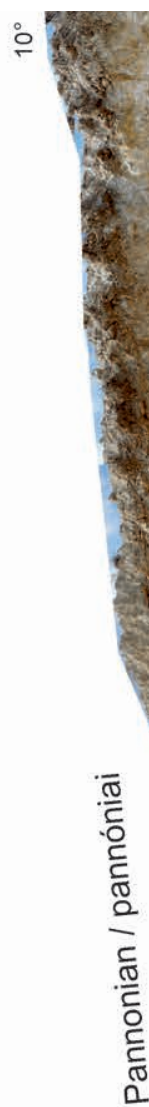

$$
\stackrel{\circ}{\circ}
$$

$\therefore$
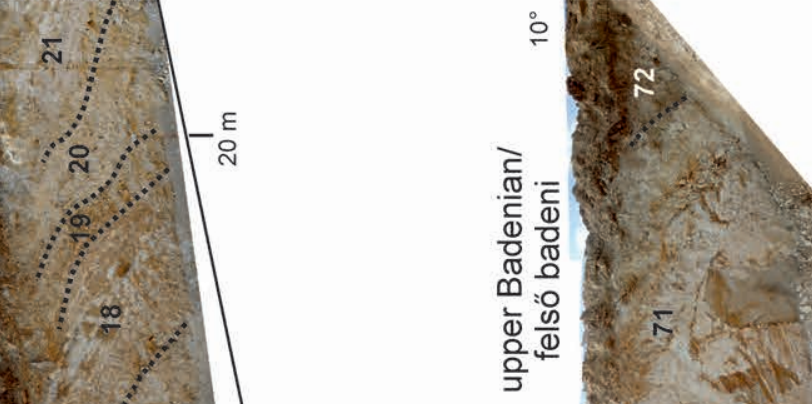


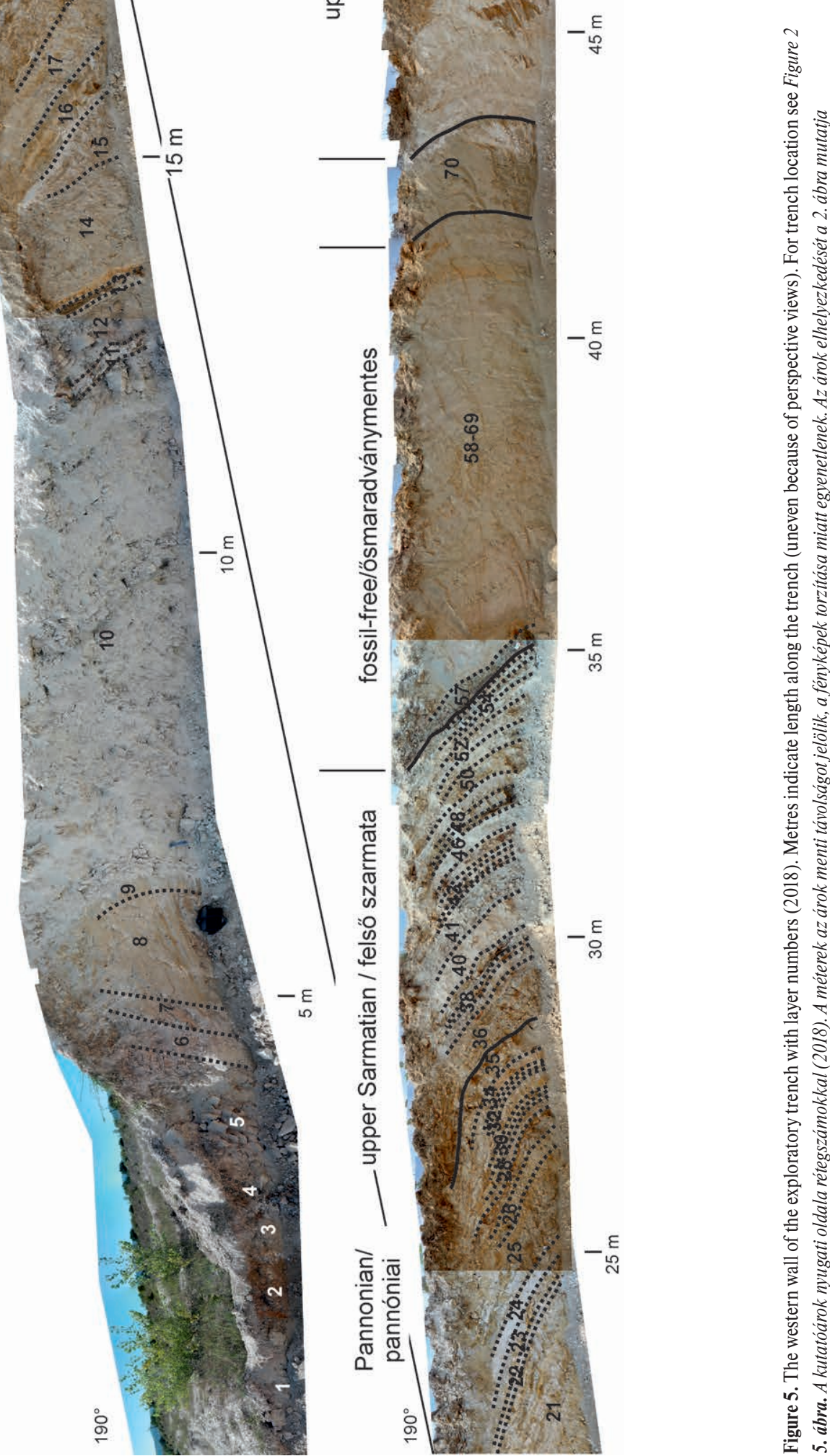

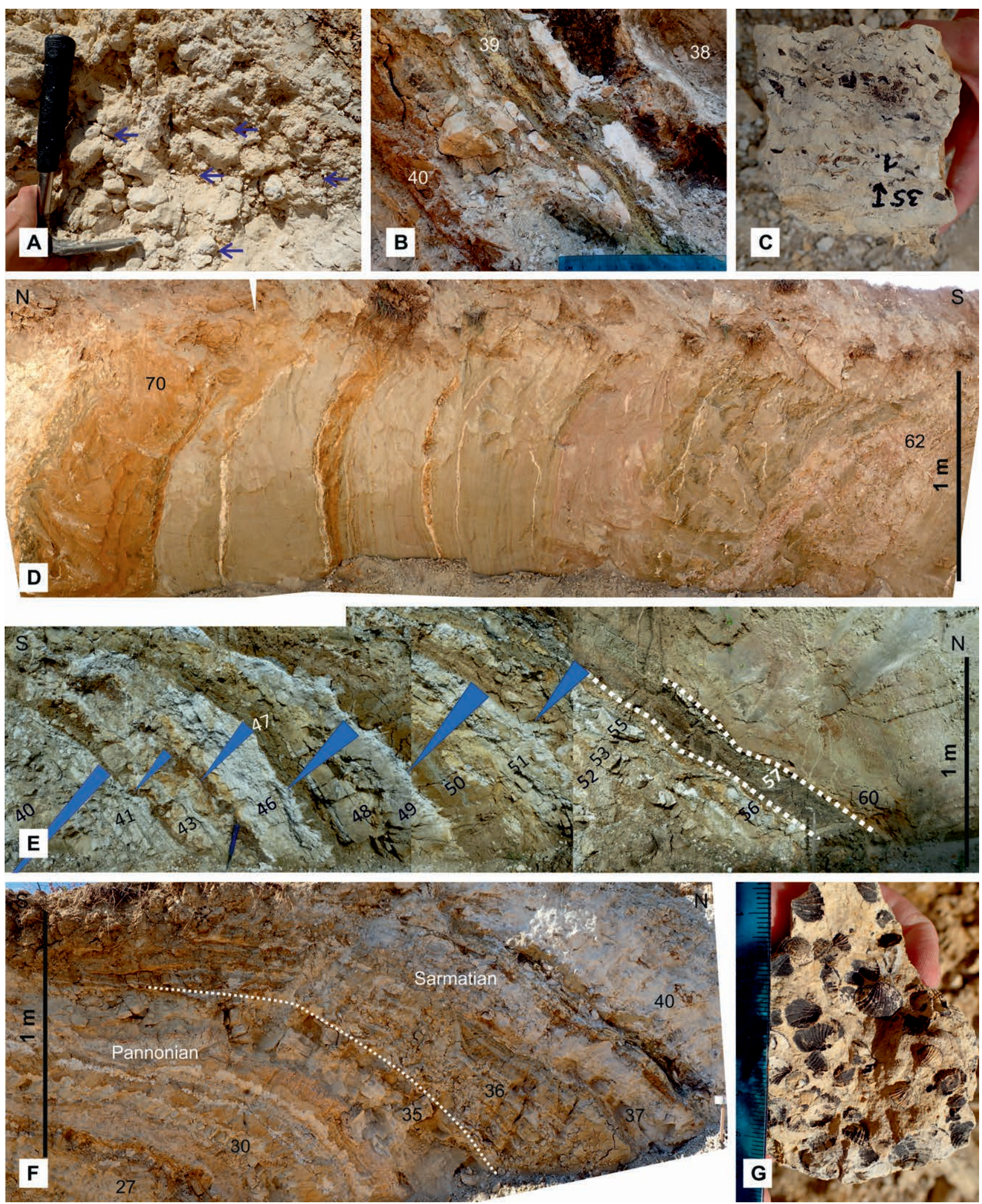

Figure 6. Typical lithofacies of the middle Miocene (Badenian and Sarmatian) and lowermost Pannonian sediments. A) Bed D71, Badenian sandy limestone, with some Cubitostrea specimens indicated by arrows; B) Sarmatian greenish yellow tuffitic clay (D39); C and G) Limestone with small Lymnocardiinae specimens, D35, base of the Pannonian succession; D) fossil-free clastics, mostly sands, with silt (e.g., D70) and gravel (D62) interbeds; E) small-scale limestone- marl-to-clay cycles in the upper Sarmatian deposits; F) the Sarmatian/Pannonian boundary within alternating clay, marl and limestone beds, as indicated by microfossils (SzUROMIKORECZ et al. 2021)

6. ábra. A középső miocén (badeni és szarmata) és legalsó pannóniai üledékek jellemzö litofáciesei. A) D71, badeni homokos mészkö; néhány Cubitostrea maradványt nyíl jelöl; B) szarmata zöldessárga tufás agyag (D39); C és G) mészkö apró Lymnocardiinae-maradványokkal, D35, a pannóniai összlet kezdete; D) ősmaradványmentes törmelékes összlet, uralkodóan homok, közetliszttel (pl. D70) és kaviccsal (D62); E) mészkö-márga-agyag ciklusok a szarmata összlet felsö részében; F) a mikrofossziliák által kijelölt szarmata-pannóniai határ a váltakozó mészkö, márga-és agyagrétegeken belül (SZUROMI-KoRECZ et al. 2021) 
fragmented by irregular fractures. Particularly near the stratigraphic top the interval consists of in situ carbonate fragmented by fractures into $40 \mathrm{~cm}$ large blocks. The rich microfauna indicated a late Badenian (early Serravallian) age (SZUROMI-KoreCZ et al. 2021).

\section{Sarmatian(?) silt, sand(stone), sandy breccia and conglomerate (beds D70-57)}

The following ca. $8 \mathrm{~m}$ thick interval is comprised of friable to moderately cemented clastic rocks (Figure $6 D$ ) barren of macrofossils. Micropaleontological investigation of silt layer D70 revealed some poorly preserved tests and fragments, which are most likely redeposited from older (Badenian) marine marls (SzUROMI-KorECZ et al. 2021). The next ca. $5 \mathrm{~m}$ is made up of $0.7-0.9 \mathrm{~m}$ thick yellow, structureless, micaceous beds of sandy silt and 1-7 cm thick clay beds, alternating with thick medium-, fine- and very fine-grained micaceous, quartz-rich sandstones. Bed contacts can be sharp or transitional. Beds are structureless or faintly laminated, normal gradation up to a thickness of $60 \mathrm{~cm}$ also occurs. The uppermost $2.5 \mathrm{~m}$ is somewhat coarser, as normally graded beds of coarse-grained granular sandstone and medium to coarse breccia with granular sandy matrix appear. The clasts are angular or subangular and immature; sorting is variable but generally poor. The uppermost, $25 \mathrm{~cm}$ thick bed (Figure $6 E$ ) consists of clayey, granular, coarse sandstone; it is variegated with dark brown manganese-limonite cementation and is capped by an unconformity.

\section{Upper Sarmatian to Pannonian clay, limestone, calcareous marl (D56-22)}

Lithologically, the Upper Sarmatian deposits and the lower part of the Pannonian ones are composed of a frequent alternation of $2-10 \mathrm{~cm}$ thick limestone, marl and clay beds (Figure 6F). There are several changes in the fossil faunas (BotKa et al. 2021, SzUROMI-KoreCZ et al. 2021, ĆORIĆ 2021) in this part of the succession, however, their positions are different for each fossil group. Therefore, an attempt was made to establish independent, physical criteria to subdivide the interval. The grain size variation is not significant; however, the bed thickness and carbonate content can be taken into consideration. The lower part shows the alternation of limestone and clay beds with an average thickness of $\sim 0.2 \mathrm{~m}$ (ranging from 6 to $50 \mathrm{~cm}$ ). The proportion of clay is slightly higher than that of carbonate (55 vs. $45 \%$ ). Limestones have a sharp base and become marly upwards, with a gradual and irregular transition to clay. This small-scale cyclicity is relatively well-developed in beds $55-52,51-50,49-47$ or $46-43$ (Figure 6E). Greenish or yellowish brown clay beds are structureless, occasionally tuffaceous (?44 and 39, Figure $6 B)$, others contain mollusk (e.g., cardiid, dreissenid) shells (beds 52, 50, 47). Very hard, micritic limestone beds mostly lack any sedimentary structures except for the finely laminated beds 51 and 48, the latter with very small bivalve and gastropod shells. Other limestone layers yielded abundant mollusks, mostly gastropods (e.g., Radix, Gyraulus in beds 43 and 37), or mass occurrences of small, delicately ornamented bivalve shells together with Hydrobiidae snails buried in life position (bed 35) (Figure 6C, G). The overall carbonate content slightly decreases upwards, thus the number of friable, structureless $(49,40,24,22)$ or laminated calcareous marl beds $(32,28)$ increases towards the younger strata.

\section{Pannonian calcareous marl and clay (D21-2)}

In the following interval the characteristic thickness of clay interbeds increases to $0.5 \mathrm{~m}$, while that of carbonate beds to up to $6 \mathrm{~m}$, with an average around $1 \mathrm{~m}$. The overall ratio of carbonate beds increases to about $75 \%$. Clays are still greenish or yellowish brown and structureless. Occasionally clay is smeared into the fractures of brecciated limestone due to postsedimentary deformation (D19). Bedding is rather indistinct in the calcareous marl, though the variation in the carbonate content is shown by varying hardness. Mollusk shells (e.g., Radix) were found only in bed 12 (Figure 7A).

\section{Pannonian calcareous marl with sandstone interbeds (D1-217)}

In this section the dominant lithology is light grey to white calcareous marl, with bed thicknesses of $10-30 \mathrm{~cm}$ (Figure 8). The carbonate content slightly fluctuates, otherwise the rock is mostly structureless. Carbonate concretions occur on the sole of some beds (Figure 7D) and along some fractures. Elsewhere bedding-parallel 1-2 cm diameter burrows were observed, filled with calcareous mudstone (Figure $7 C$ ). Some of the beds host abundant mollusk shells, bivalves and gastropods (BOTKA et al. 2021), and large ostracod carapaxes are also fairly common (CsOMA et al. 2021).

Higher up in the succession intercalations of greyish green clays, grey siltstones, and friable, weakly cemented very fine to medium-grained sandstone and conglomerate beds occur. Their thickness increases upwards (from $20 \mathrm{~cm}$ to $1 \mathrm{~m}$ ), and so does their frequency, hence the proportion of carbonate beds decreases to ca. $70 \%$ in the uppermost $10 \mathrm{~m}$ (see beds in Figure 4). Conglomerates have a sharp erosive base and they are normally graded from medium-grained

$\rightarrow$ Figure 7. Lithofacies of the upper Miocene calcareous marl succession. A) calcareous marl with mollusks (e.g., Radix croatica, Gyraulus tenuistriatus, "Lymnocardium" cf. praeponticum) (D12); B) tuff in calcareous marl (D205); C) bedding-parallel burrows from the upper part of the marl; D) concretions along a bedding plane of the calcareous marl; E) clay and normally graded gravelly sand and sandstone within the calcareous marl succession; F) moulds of littoral gastropods in sandstone (D215); G) the boundary of the calcareous marls and the transitional silt-sand unit; H) large Congeria partschi and Lymnocardium schedelianum shells in the transitional silts (D219)

$\rightarrow 7$ ábra. A felső miocén mészmárgasorozat jellemzó litofáciesei. A) mészmárga puhatestüekkel (pl. Radix croatica, Gyraulus tenuistriatus, "Lymnocardium" $c f$. praeponticum) (D12); B) tufa mészmárgában (D205); C) réteglappal párhuzamos ásásnyomok a mészmárga felső részéböl; D) konkréciók mészmárga réteglapján; E) agyag-és gradált kavicsos homok-betelepülés mészmárgában; F) sekélyvízi csigák lenyomatai homokkőben (D215); G) a mészmárga és az átmeneti aleurithomok egység határa; H) Congeria partschi és Lymnocardium schedelianum kagylóhéjak aleuritban az átmeneti egységben (D219) 

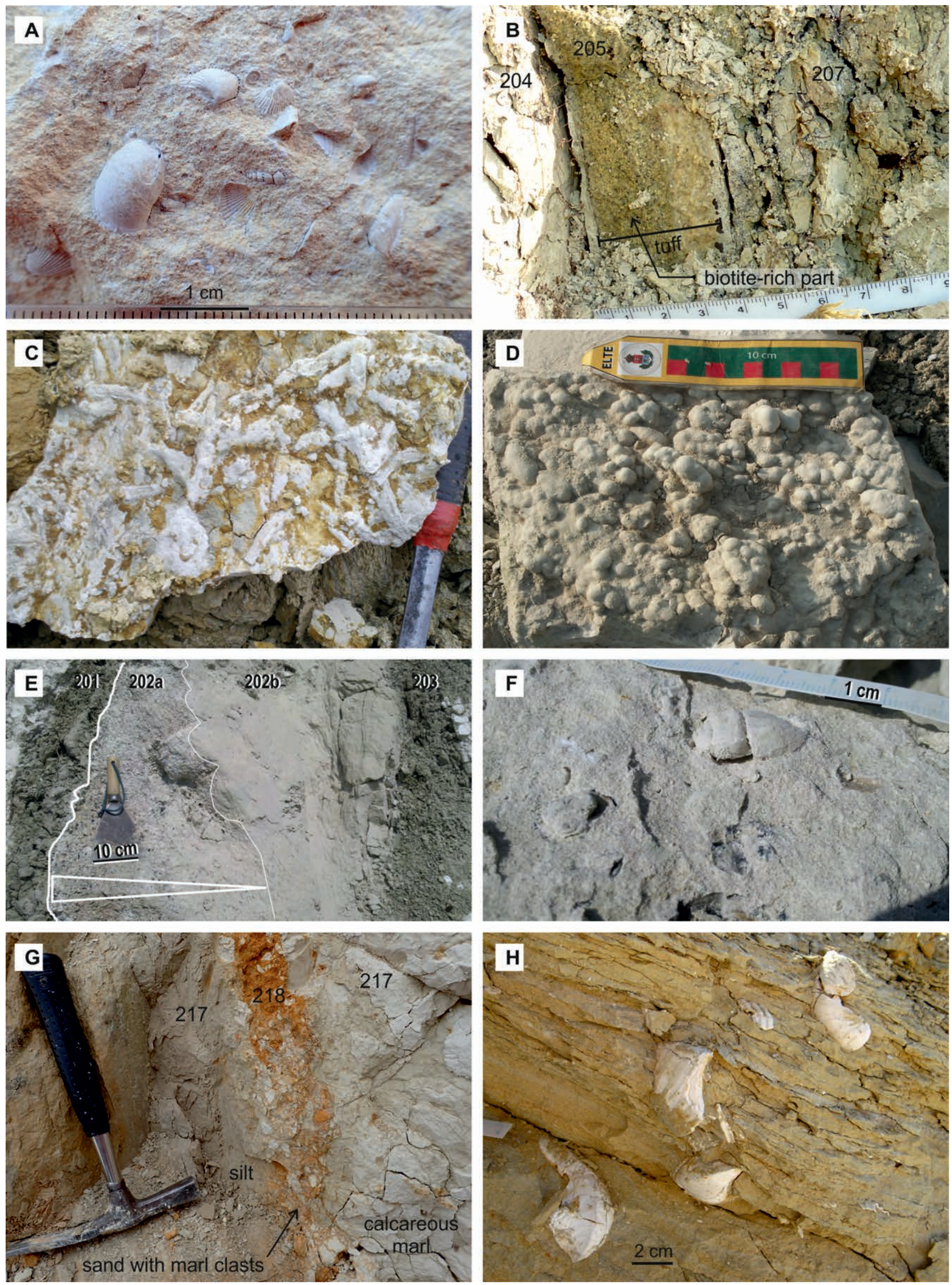

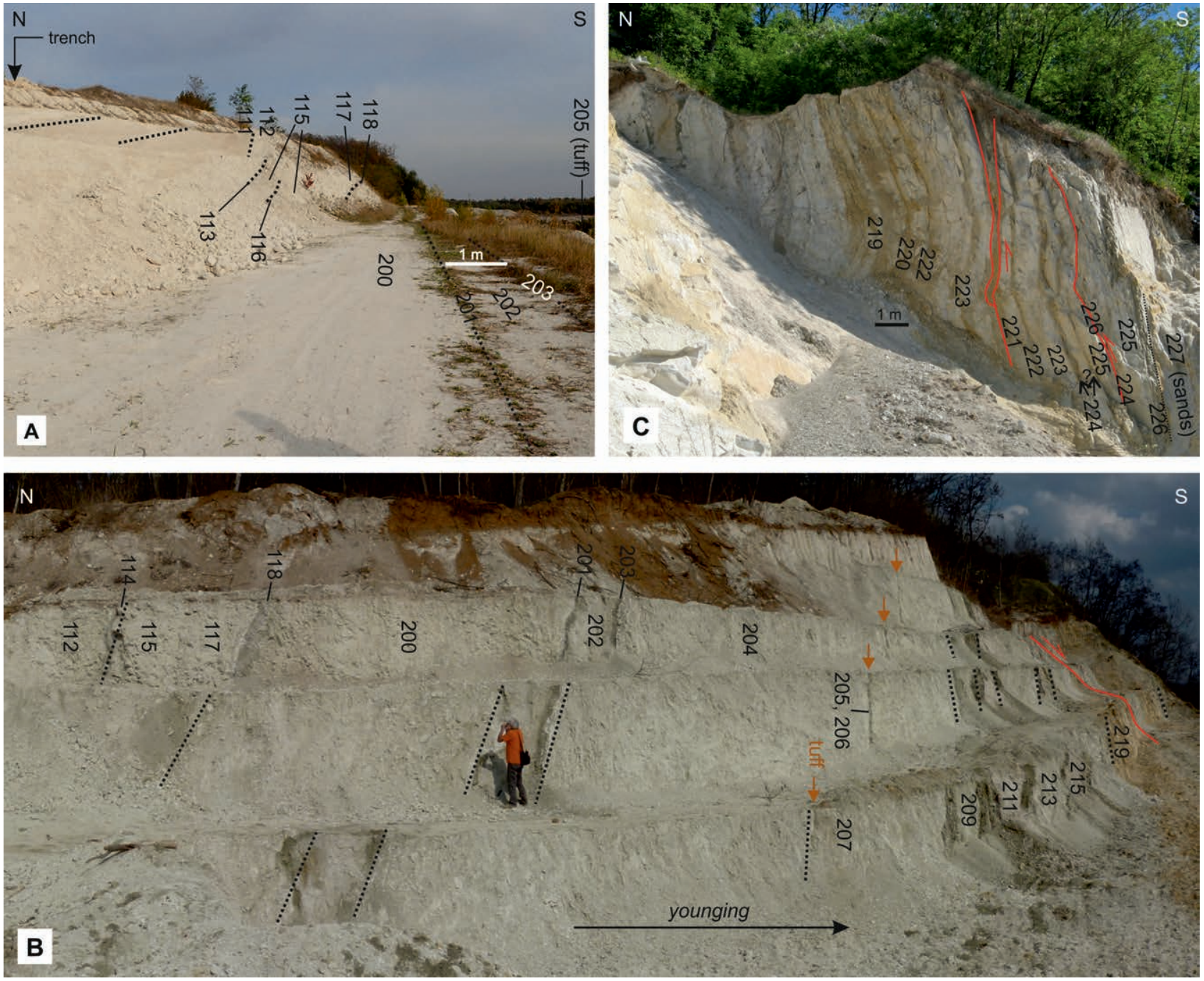

Figure 8. The upper part of the Pannonian carbonate-dominated succession in the northern part of the sand pit, with layer numbers. A) Sections 2-3 immediately south of the trench pictured in 2018; B) section 5 in 2012; C) section 7 in 2015. For section locations see Figure 2

8. ábra. A pannóniai mészmárgarétegsor felsô része a bánya északi oldalán, rétegszámokkal. A) 2. és 3. szelvény közvetlenül az ároktól délre, 2018-ban; B) 5. szelvény 2012ben;C) 7. szelvény 2015-ben. A szelvények elhelyezkedése a 2. ábrán látható

gravel to granular sand. Most sandstones are well-sorted, oligomictic, quartz-rich and structureless; their boundaries are sharp, erosive, or might show ball and flame structures. They occasionally contain vertebrate remains, e.g., fish teeth and bones and turtle shell fragments. D215 contains compressed gastropods and bivalve shells (Figure $7 F$ ). A greyish green clay bed (D205) contains abundant euhedral biotites and volcanic glass pointing to an ashfall tuff (SEBE et al. 2016); preliminary investigations identified it as an alkaline trachyte tuff (Figure $7 B$ ). Poorly preserved mollusks are present in D216 and 212.

Pannonian sandstone, silty clay, siltstone: transitional beds between the marls and the limonitic, pebbly sandstone (D218-226)

The topmost ca. $6 \mathrm{~m}$ of the fine-grained succession consists of alternations of yellow fossiliferous silty marl, clayey siltstone, siltstone and friable, quartz-rich very fine to me- dium-grained structureless sandstone, representing a transition towards the overlying sandstone unit. These beds contain abundant macrofloral remains, mostly leaves and branch fragments and some fruits (HABLY \& SEBE 2016). The top of the youngest marl bed is irregular with a few $\mathrm{cm}$ deep, cylindrical or funnel-shaped burrows filled with the overlying sand. This sand bed (D218) also contains cm-sized rip-up marl clasts and large amounts of mollusk shell fragments (Figure $7 G$ ). The interval contained a rich profundal mollusk assemblage (BоTKA et al. 2021) (Figure 7H).

\section{Pannonian limonitic, pebbly sand(stone) (D227-)}

The next ca. $140 \mathrm{~m}$ thick succession is divided into two parts by an angular unconformity (Figure $2 B, 9 A$ ) in the western wall of the sand pit; in the NE wall only the portion below the unconformity is exposed. The lower, relatively steeply dipping series is further subdivided by a grey, ca. 
0.4-0.5 m thick clayey silt bed (at $170 \mathrm{~m}$ in Figure 4). The majority of the succession is built up of alternating layers of coarse to very coarse, partly pebbly sand and granule to pebble sized gravel. The deposits are sandstones and conglomerates cemented by limonite and are friable to loosely cemented. As the majority of the rock crumbles easily, for the sake of simplicity the term 'limonitic sand' is used for the entire section hereafter. Beds are parallel, with thickness ranging from a few tens of $\mathrm{cm}$-s to a few metres, they are marked by minor fluctuations of grain size and sorting, i.e. the ratio of sand to gravel. Metre-scale beds can be differentiated mostly by limonite colouring, otherwise it is difficult to distinguish layers, as bed contacts commonly are transitional. Gravel intervals are poorly sorted, consisting mostly of subangular to moderately rounded granules and medium to coarse pebbles. In the pebbly sand beds the ratio of gravel varies between 5 and 50\% (Figure 9C). The clasts have a polimictic composition with the dominance of quartzite. Lithics and some feldspars are possibly - perhaps indirectly - derived from a granitoid source area, others come from the reworking of older Miocene clastics (mostly from Szászvár and Budafa Formations). Locally, rip-up mud clasts up to a diameter of cobble are dispersed in the pebbly sand (Figure 9D). The sand body contains limonite-cemented moulds of Lake Pannon mollusks. Vertebrate remains, among them marine fish and mammal fossils reworked from middle Miocene deposits, are also common.

In the lower part of the pebbly sand succession (Figure 4) $1 \mathrm{~m}$ wide and $10-15 \mathrm{~cm}$ deep scours or lenses appear. Although well-developed grading is rarely present, in many cases the low-relief rough erosional surfaces are often overlain by the coarsest fraction or the largest concentration of gravel. Some irregular, slightly elongated patches of fine, medium and coarse-grained sand appear, without forming distinct burrows. Somewhat below the silt layer at $170 \mathrm{~m}$ (Figure 4), a ca. $30 \mathrm{~cm}$ thick, clast- supported coarse pebbleto cobble mud-clast conglomerate occurs with coarse, very coarse sand matrix and sharp erosional base (Figure 9D). The erosional base of another bed at $168.5 \mathrm{~m}$ is also paved by small mud-clasts (Figure 9E). These beds cut into the "regular" pebbly sand, which is directly overlain by the thick silt marker bed at $170 \mathrm{~m}$ within a 20-30 m distance.

Above the angular unconformity at $171 \mathrm{~m}$ mostly parallel beds occur without pronounced changes of the lithology, average grain size, clast shape or sorting with respect to the sediments below. The first bed is a normally graded coarse conglomerate with a thickness of $\sim 1 \mathrm{~m}$. It contains exceptionally well-rounded Paleozoic granite and Permian rhyolite cobbles of up to $15 \mathrm{~cm}$ diameter, which originate from the lower and middle Miocene Szászvár and Budafa Formations (Figure 9C). The graded conglomerate bed interfingers with well-sorted arcosic coarse grained sandstone, which can be followed for several tens of metres above the unconformity. A few limonite cemented marker beds also help to correlate the succession. The youngest part of the succession consists of metre-thick beds of coarse and very coarse sandstone as well as poorly sorted pebbly sandstone, with angular quartzite clasts. The topmost bed contains well-rounded pebbles made up of rhyolite tuff. The lack of traction-induced primary sedimentary structures (such as cross-bedding) in the sandstones and gravelly sandstones is evident both below and above the unconformity.

\section{Interpretation}

\section{Lithostratigraphy and depositional environments}

The classification of the exposed sediments into lithostratigraphic units is not straightforward. Several of the Miocene formations previously reported from the area include various lithologies, thus paleontological data are necessary to identify them. However, our studies showed that different fossil groups may show pronounced changes asynchronously in the sedimentary succession. This phenomenon has also been reported from the Paratethys, e.g., in the Vienna Basin, around the Badenian/Sarmatian boundary (HYŽNÝ et al. 2012). The identification of chrono- and lithostratigraphic units, therefore, remains somewhat ambiguous. Hereby, we suggest a sub-division of the studied deposits into stratigraphic units based on the integration of the observed lithofacies variations and fossil assemblages.

Szilágy Clay marl Member of the Baden Formation or Rákos Member of Lajta Limestone Formation (upper Badenian)

The topmost part of the unit was exposed in the northern end of the trench and is represented by the yellowish white calcareous marl of layer D72. The rock contains a typical Badenian mollusk fauna, where all bivalves are inbenthos species in fine-grained deposits, referring to several tens of metres of water depth (DULAI et al. 2021). The microfauna belongs to the upper Badenian Bolivina-Bulimina Zone (13.82-12.65 Ma) and indicates agitated, relatively shallow water with normal salinity (SzUROMI-KoRECZ et al. 2021); it must have been reworked into water depths below wave base. The sediments exposed in the trench, similarly to those in the surrounding area (HÁMOR et al. 1968), contain more carbonate than the typical Szilágy Clay marl. Therefore, this unit can be classified as Szilágy Clay marl if the carbonate content, the sublittoral depositional environment and the existing stratigraphy of the region is considered, but can also be regarded as a deeper water interval of the overlying Lajta Limestone Fm. The depositional environment might have been located close to the nearshore.

\section{Rákos Member of the Lajta Limestone Formation (upper Badenian)}

The $\sim 3 \mathrm{~m}$ thick sandy limestone and calcarenite of layer D71 in the trench shows the typical features of the "Leitha limestone": carbonate-rich sediment with a rich macro- and microfauna pointing to shallow and agitated water (DuLAI et al. 2021, SzUROMI-KoreCZ et al. 2021). The microfauna indicates a late Badenian age. Based on its stratigraphic posi- 


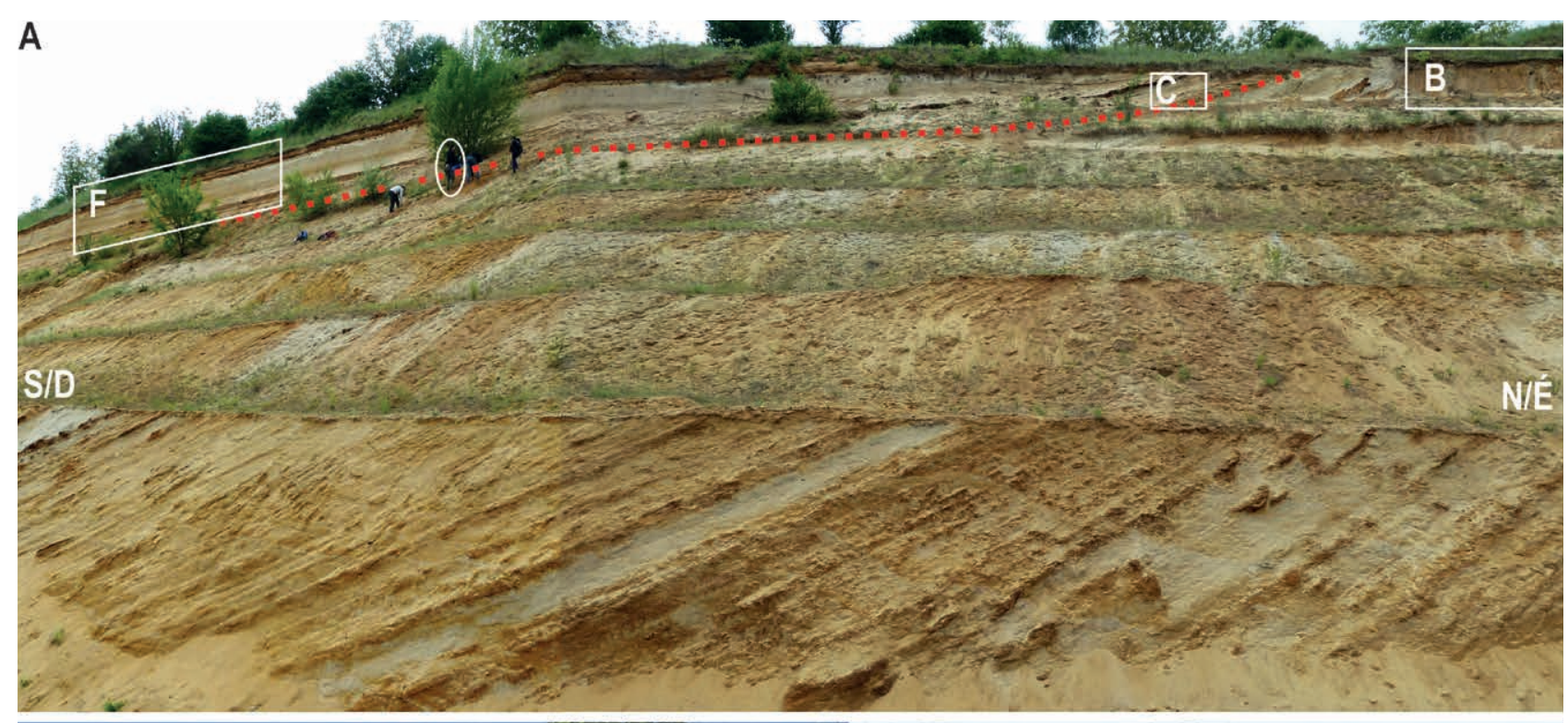

B S/D
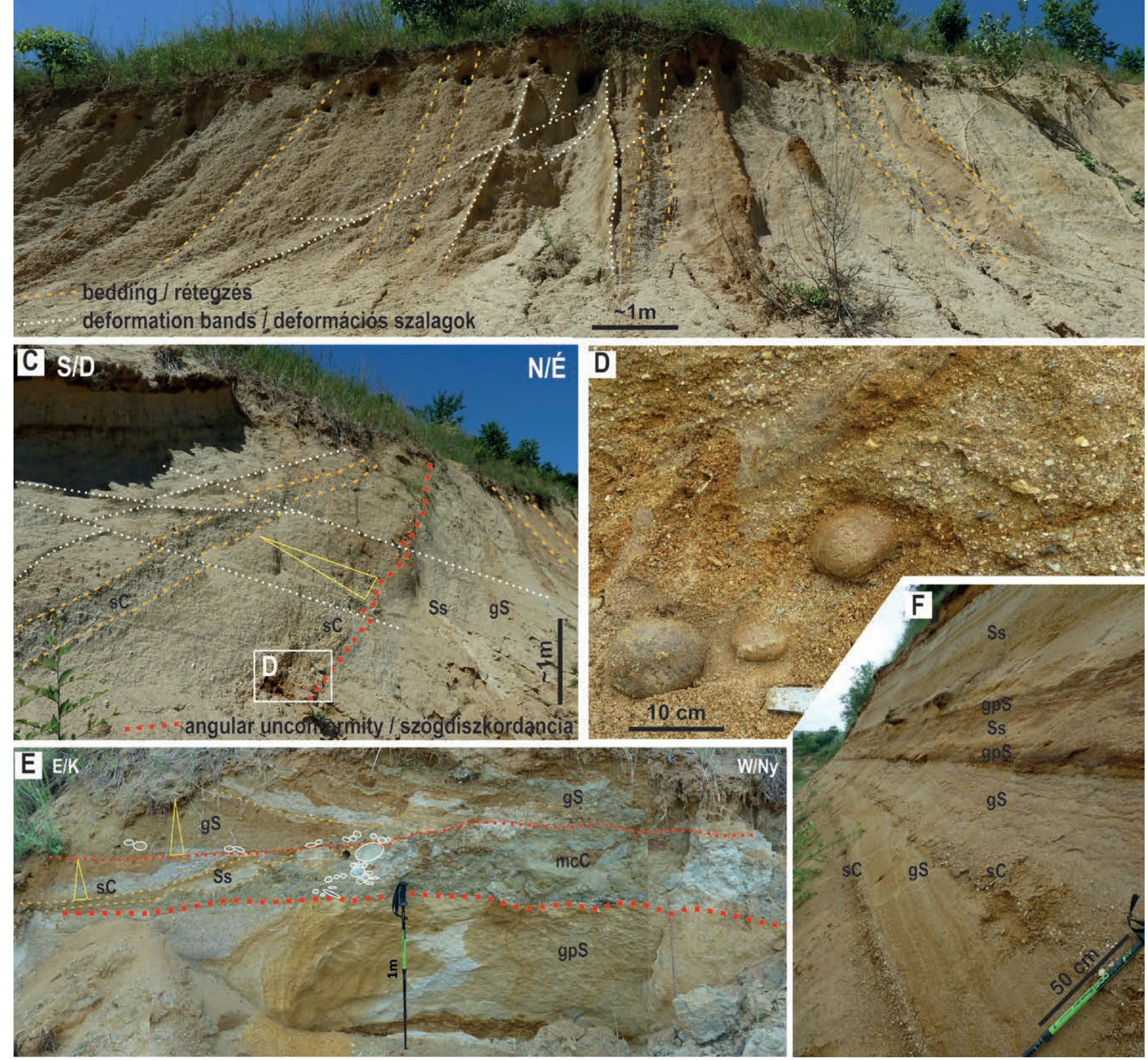
tion (above and/or interfingering with the Szilágy Clay marl and directly below the Sarmatian rocks) and because of the late Badenian age, these layers can be identified as the upper part (Rákos Member) of the Lajta Limestone Formation. In the Mecsek mountains HÁMOR et al. (1968) and HÁMOR (1970) defined the Szilágy Clay marl to include the "upper Leitha limestone", adding that the limestone represents a nearshore environment and interfingers with the open-water clay marl. However, in the surroundings of Danitzpuszta, the limestone occurs in a well-defined, narrow belt including the exposure of the trench. Therefore, it is more informative to differentiate these two stratigraphic units.

\section{Kozárd Formation (Sarmatian)}

The interval between layers D70 to D36 is sharply divided into two different units: the lower, ca. 7-8 m thick part from D70 to D57 includes silt, sand(stone) and conglomerate, whereas the overlying ca. $5 \mathrm{~m}$ show cyclic alternation of thin clay, marl and limestone (D57-D36). The yellowish brown silt of D70 has a reworked microfauna with Badenian elements, poorer but similar to D71 (SzUROMI- KorECZ et al. 2021). Based on its lithological similarity to the overlying interval, we tentatively classify this layer as Sarmatian as well. Beds D69 to D57 sampled for microfauna investigations contained no microfossils, thus their age is uncertain. The lack of normal salinity marine microfauna points either to terrestrial exposure, or to deposition under variable salinity conditions during the Sarmatian. The age of beds D54 to D36 is indicated by the microfauna as late Sarmatian, 12.1-11.6 Ma (SzUROMI-KoreCZ et al. 2021). The variable salinity of the otherwise brackish Sarmatian sea is supported by the biota of layers D37-40, which show the influence of freshwater inflow as demonstrated by the microfauna, the nannoplankton and the mollusks as well (SzUROMI-KorECZ et al. 2021, ĆORIĆ 2021, BOTKA et al. 2021).

In the clastic succession there are no sedimentary structures pointing to traction currents. Poor sorting, angular clasts, erosive bed contacts and few graded beds may point to rapid deposition from small-volume, either subaerial or subaqueous gravity-driven flows. Considering the lack of

$\leftarrow$ Figure 9. Typical lithofacies of the upper Miocene sands. A) alternating coarse and granular very coarse sands with varying limonite cementation. People for scale. The locations of other inserts are indicated. B) steep beds with deformation bands in the upper part of the western wall of the sand pit; C) close-up of the angular unconformity and some reverse faults; for facies codes see Table I; D) poorly sorted sandy gravel with well-rounded cobbles above the unconformity; E) granular, pebbly coarse sand $(\mathrm{gPcS})$ overlain erosively by a mud-clast conglomerate (MCC) and granular coarse sand $(\mathrm{GcS})$ beds in the middle of the succession (beds at $168 \mathrm{~m}$ of Figure 4); F) parallel beds of structureless coarse sand and coarse pebble gravel above the unconformity

$\leftarrow 9$. ábra. A felsö miocén homokösszlet jellemzö litofáciesei. A) nagyszemü és darakavicsos durvaszemü homok váltakozása, változó mértékü limonitos cementációval, a részletfotók helyének jelölésével; $B$ ) Meredeken dölö rétegek a bánya nyugati falának fölső részében; C) a diszkordanciafelszín közelképe néhány feltolódással; a litofácies-kódok magyarázatát az I. táblázat tartalmazza; D) rosszul osztályozott homokos kavics a diszkordanciafelszín fölött,joól koptatott hömpölyökkel; E) kavicsos nagyszemü homok (gPcS), fölötte eróziós felszín fölött agyagkavics-konglomerátum (MCC) és darakavicsos nagyszemü homok (GcS) a homokösszlet közepe táján (168 $m$ körüli rétegek a 4. ábra rétegsorán); F) szerkezetmentes nagyszemü homok és nagyszemü kavics párhuzamos rétegei a diszkordanciafelszín fölött fossils, an alluvial or lacustrine fan-like depositional setting is likely. The Fe-Mn encrusted unconformity on top of layer D57, the appearance of clays, marls and limestones above, together with the appearance of fossils denote a sharp change in the depositional environment, probably from terrestrial to (brackish) marine. The overlying mudstones, regardless of their carbonate content, indicate deposition in quiet waters, devoid of wave agitation or intermittent currents, which could have transported sand into the system. The microfauna also supports sublittoral water depths (SzUROMI-KORECZ et al. 2021). Based on these, a rapid transgression, resulting in a water depth below storm wave base (few tens of meters) and/or large distance to the source area and/ or a palaeogeography preventing coarse clastic input is inferred. Based on the high proportion of fine-grained sediments - clays and marls -, this interval is assigned to the Kozárd Formation. The Sarmatian interval exposed in the trench is significantly thinner than the thickness considered typical of the area from borehole data $(120-150 \mathrm{~m}$ in the Pécsbánya Basin west of the sand pit; HÁMOR et al. 1968) or that inferred from dips and areal distributions indicated in maps (HÁMOR et al. 1966, HETÉNYI et al. 1982).

\section{Endrőd Formation (Pannonian)}

The layers D35 to D225, with a total thickness of $64 \mathrm{~m}$ are assigned to Endrôd Formation. The lower part of this unit (beds D35-D22) is lithologically very similar to the upper part of the underlying Kozárd Fm., hence the boundary was defined based on micropaleontological results: the last occurrence of the typical Sarmatian marine foraminifers was found in layer D36 (SzUROMI-KoRECZ et al. 2021), whereas the first occurrence of typical Lake Pannon ostracods is located in layer D35 (Csoma et al. 2021). In addition, the cyclic lithological pattern becomes less evident upwards, though the alternation of limestone and clay beds persists. Upsection from D14, gradually thickening, homogeneous marl intervals become dominant with some graded or structureless conglomerate to sandstone interbeds. Their deposition took place in open, probably a few hundred metres deep waters, most likely below or on a slope. This can be deduced from the occurrence of $0.5-2 \mathrm{~m}$ thick coarse pebbly to sandy turbidite beds, in accordance with the palynofacies and the appearance of profundal mollusks (KRIZMANIĆ et al. 2021, BOTKA et al. 2021). The material of clastic interbeds originated from the dryland in the north. This could have been an island at that time, as shown by the areal distribution of coeval sediments (KLEB 1973, MAGYAR et al. 1999). The island was elongated in the WSW-ENE direction and had dimensions of 10-15 km $\times$ $30-40 \mathrm{~km}$. Both the size of the dryland and the sediment types are comparable to those of the Battonya High in the E Pannonian Basin (MagYAR et al. 2004).

Within the Endrőd Fm. most of the Danitzpuszta section (up to D217) represents the Tótkomlós Calcareous marl Member. The sand pit is a rare surface occurrence of this unit known from thousands of wells in the subsurface of the Pannonian Basin. The few other studied outcrops of these deposits are located in Croatia (e.g., Našice, Kovačıć et al. 
2017, SEBE et al. 2020) and Serbia (Beočin, TER BorGH et al. 2013). The uppermost 6-7 metres, between layers D218 and D226, show a transition towards the overlying sands, with the increase of siliciclastic compounds and a decrease of carbonate content.

It must also be noted that the outcrop offers a special detailed view on the Sarmatian/Pannonian boundary. The position of this boundary is not obvious, as there are discrepancies between the major changes in the different fossil groups. This highlights an interpretation pitfall, even if almost all beds are investigated. In the mollusk fauna the first appearance of Pannonian lymnocardiids (Lymnocardium praeponticum) coincides with the first appearance of Lake Pannon ostracods in layer 35 (BоTKA et al. 2021, CsomA et al. 2021). However, Sarmatian-type cardiids remain dominant in layers 35-33, and they only disappear completely in bed 12. In the nannoplankton record, the dominance of endemic Lake Pannon taxa only starts in layer 20 (ĆORIĆ 2021), close to the position where calcareous marl becomes dominant against the limestone-marl-clay cycles (layer 22). Discrepancies between the positions of the Sarmatian/Pannonian boundary based on different fossil groups - typically mollusks, foraminifers and ostracods, organic walled microplankton and calcareous nannoplankton - have also been reported from other localities (HALMAI et al. 1982, JÁMBOR et al. 1987, KóKAY et al. 1991, HÁMOR 1992), in a transitional interval of mostly calcareous marls, previously defined as the Zala Member of the Endrőd Formation (JÁMBOR 1980). This boundary question definitely needs further investigations.

The lowermost part of the calcareous marls (beds D35D12) contains a mollusk assemblage of the Lymnocardium praeponticum sublittoral mollusk biozone $(\sim 11.62-11.45$ $\mathrm{Ma}$ ), the lowest zone of Lake Pannon sediments (BоTKA et al. 2021). Upward the fauna changes into an assemblage representing the Congeria banatica profundal mollusk biozone ( 11.45-9.6 Ma) without a sharp change in lithology. Within this sediment interval, dinocysts in beds D3-D1 indicate Pontiadinium pecsvaradensis dinoflagellate Zone (ca. 10.8 to $10.6 \mathrm{Ma}$ ) (KRIZMANić et al. 2021). The transitional silt-sand unit (D218-226) belongs to the Lymnocardium schedelianum sublittoral mollusk Zone (11-10.2 Ma). Within this zone, the morphologies of some bivalve species (e.g., Lymnocardium schedelianum, L. aff. boeckhi) and interregional correlation of the mollusk fauna place the top of the unit between 10.5 and 10.2 Ma (BоTKA et al. 2021).

\section{Kálla Member of the Békés Formation (Pannonian)}

Coarse, gravelly sands from layer 227 upwards were derived from a local source area in the Mecsek Mts. The total thickness of clastic strata exposed in the sand pit exceeds $100 \mathrm{~m}$ and may attain $140 \mathrm{~m}$. This unit has been classified into the Kálla Formation (now a member of the Békés Formation) because of its local source. However, the sedimentary features, the large-scale depositional architecture, the depositional system or its stratigraphic position is different from the typical occurrences of the Kálla Member (cf.,
SzTANó et al. 2010, Csillag et al. 2010, Tóth et al. 2010, MAGYAR et al. 2016).

Any shallow-water setting with wave or current activity can be excluded based on the absence of bedforms indicative for traction currents. Instead, the relatively large bed thickness (or amalgamation), the parallel bedding planes and the occasional occurrence of graded beds points to large-volume gravity-driven flows. No slide or slump structures indicating a sloping topography at the site of accumulation were observed. Initially, the depositional depth might have been as large as for the marl, providing enough space for the deposition of at least 100-140 m of coarse clastics. Most likely fans or fan deltas could have developed near the source area (the Mecsek Mts), while the studied coarse sands formed as deep-water lobe deposits in their distal continuation. Finally, typical Kálla beds and other members of the Békés Formation are transgressive deposits, being covered by open lacustrine marls, but the strata in Danitzpuszta reflect an opposite trend. Flooding of the area is indicated by the underlying calcareous marl, while the appearance of the coarse clastics reflects regressive processes. The opening of new sediment sources and/or transport routes may have been driven by a local base level fall. The coeval coastal to nearshore deposits, i.e., coarsegrained deltas representing the typical Kálla beds, may be eroded by now, hence the succession can be regarded as an unusual, distal variety of the Kálla Member. The trigger for sand deposition remains unclear. The most obvious candidate to initiate erosion and clastic input in the area is the start of compression and thus the uplift of the mountains. However, it seems to post-date the onset of sand accumulation (SEBE 2021). An increasingly humid climate and the corresponding higher erosion potential has been reconstructed for 9.7-9.2 Ma for the Pannonian Basin (MAgYar 2010), at least 0.5 Ma after the onset of sand deposition. The re-arrangement of sediment pathways on the lakefloor due to local tectonic activity might have been a triggering factor; however, no evidence is available at the moment to prove this.

The age of sand deposition is constrained partly by the underlying marls (see above). The mollusk assemblages collected from all parts of the gravelly sands, including those above the unconformity, are identical. They belong to the upper part of the Lymnocardium conjungens littoral mollusk biozone (9.6-11.0 Ma); within this interval the sands were probably deposited between 10.2 and $10.0 \mathrm{Ma}$ (BоTKA et al. 2021).

\section{Evolution history}

The Danitzpuszta succession records a complex chain of events from the Badenian Paratethys to Lake Pannon. The succession represents an area in the vicinity of an island surrounded by shallow sea, where calcareous marls and shallow water carbonate sands accumulated during the late Badenian. When fully marine deposition ceased, the area became either subaerially exposed or deposition continued in brackish waters sometime between the latest Badenian and the late Sarmatian, probably with a topographic relief 
allowing the formation of fans. In the late Sarmatian the area became flooded again. Sedimentation took place in sublittoral brackish water, while the sediment sources were distal or topographically limited. Environmental conditions hardly changed when the Paratethys was replaced by Lake Pannon, but a gradual deepening took place and the deposition of calcareous marls became dominant. The overlying siltstone and sandstone beds indicate a gradual increase of siliciclastic input, revealing the exposure of a nearby source area or a re-arrangement of the sediment feeder system. The accumulation of coarse, pebbly sands commenced from gravity flows on deep-water portions of fan deltas.

\section{Conclusions}

The sand pit and the trench in Pécs-Danitzpuszta exposed a continuous sedimentary succession with a true thickness of ca. 220 metres. They offer an exceptional outcrop of late Badenian to early Pannonian marine, terrestrial and lacustrine deposits and give information on more than 4 Ma of changing paleoenvironments in and near the Central Paratethys sea and Lake Pannon. The outcrop provided a surface occurrence of a continuous Sarmatian/Pannonian boundary section, where the deposition appears to have been fairly continuous, and microand macrofauna need to be used to locate the boundary. However, there are discrepancies between the potential boundaries indicated by molluscs, foraminifers, ostracods and calcareous nannoplankton, calling attention to the fact that differentiating Sarmatian and Pannonian deposits formed in similar environments can be problematic in the field. The site is also a unique, well-accessible surface exposure of the deep lacustrine Endrôd Marl that formed in a paleogeographic setting analogous to many of its subsurface occurrences.

\section{Acknowledgements}

First and foremost, we express our gratitude to Béla MolnÁR, Ernő BüKI and Gyöngyi SzŐLősi (Quartz Kft.) for supporting our work for over 20 years; they also had the exploratory trench excavated in 2018. Research was further supported by the OTKA/NKFIH (Hungarian National Research, Development and Innovation Office) projects PD104937 and 116618, by the projects 20765-3/2018/ FEKUTSTRAT and EFOP-3.6.1.-16-2016-00004 of the University of Pécs, and by the Bolyai János Research Scholarship of the Hungarian Academy of Sciences and the TÁMOP 4.2.4. A/2-11-1-2012- 0001 'National Excellence Program' (Zoltán Magyary Grant) to KS. We are grateful to Imre MAGYAR and Ildikó SELMECZI for discussions on stratigraphy, and to Ádám KovÁCS and Imre MAGYAR for field assistance. The detailed reviews of András UHRIN and Samuel RYBÁR greatly improved the manuscript.

\section{References - Irodalom}

BARTHA F. 1971: A magyarországi pannon biosztratigráfiai vizsgálata [Biostratigraphic investigation of the Pannonian in Hungary]. - In: GócZÁn F. \& BENKŐ J. 1971: A magyarországi pannonkori képzôdmények kutatásai [Studies in Pannonian deposits in Hungary]. Akadémiai Kiadó, Budapest, 9-172.

BotKa, D., Rofrics, N., Katona, L. \& Magyar, I. 2021: Pannonian and Sarmatian mollusks from Pécs-Danitzpuszta, southern Hungary: a unique local faunal succession. - Földtani Közlöny 151/4, 335-362.

CHikán G.\& Budai T. 2005: Magyarország földtani térképe, Pécs (L-34-61) 1:100 000 térképlap [Geological map of Hungary, 1:100 000 sheet Pécs (L-34-61)]. - Geological Institute of Hungary, Budapest.

Ć́nIĆ, S. 2021: Calcareous nannofossils from the middle/upper Miocene succession of Pécs-Danitzpuszta, southern Hungary: cosmopolitan Paratethys and endemic Lake Pannon assemblages. - Földtani Közlöny 151/3, 253-266.

Csillag G., Sztanó O., Magyar I. \& Hámori Z. 2010: A Kállai Kavics települési helyzete a Tapolcai-medencében geoelektromos szelvények és fúrási adatok tükrében (Stratigraphy of the Kálla Gravel in Tapolca Basin based on multi-electrode probing and well data). - Földtani Közlöny 140/2, 183-196.

Csoma, V., Magyar, I., Szuromi-Korecz, A., Sebe, K., Sztanó, O., Buczkó, K. \& Tóth, E. 2021: Pannonian (late Miocene) ostracod fauna from Pécs-Danitzpuszta in Southern Hungary. - Földtani Közlöny 151/3, 305-326.

Dulai, A., Henn, T. \& Sebe, K. 2021: Middle Miocene (Badenian) macroinvertebrates from Pécs-Danitzpuszta (Mecsek Mts., SW Hungary). - Földtani Közlöny 151/4, 329-334.

Hably, L. \& SEbe, K. 2016: A late Miocene thermophilous flora from Pécs-Danitzpuszta, Mecsek Mts., Hungary. - Neues Jahrbuch für Geologie und Paläontologie 279/3, 261-271. https://doi.org/10.1127/njgpa/2016/0554

Halmai J., JÁmbor Á., RAVASZ-BARANYAi L. \& Vetó I. 1982: Geological results of the borehole Tengelic-2. - Annals of the Geological Institute of Hungary $\mathbf{6 5}, 11-113$.

HÁMOR G. 1970: A Kelet-mecseki miocén [Miocene of the Eastern Mecsek Mts.]. - Annals of the Geological Institute of Hungary 53/1, 371 p.

HÁMOR G., NAGY E. \& FÖLDI M. 1966: Magyarország földtani térképe, 10 000-es sorozat, Pécs-Meszes [Geological maps of Hungary, 1:10000 scale series, Pécs-Meszes]. - Geological Institute of Hungary, Budapest.

HÁMOR G., NAGY E.\& Földi M. 1968: Magyarázó a Mecsek hegység földtani térképéhez. 10 000-es sorozat. Pécs-Meszes [Explanations to the Geological map of the Mecsek Mountains. 1:10 000 scale series, Pécs-Meszes]. - Geological Institute of Hungary, Budapest, 54 p.

HÁMOR T. 1992: A Szirák-2. sz. alapfúrás földtani eredményei [Geological results of the borehole Szirák-2]. - Annual Report of the Geological Institute of Hungary on 1990, 139-168.

Hetényi R., HÁmor G., Földi M., NAGy I., NAGy E. \& Bilik I. 1982: A Keleti-Mecsek földtani térképe. 1:25 000. - Geological Institute of Hungary, Budapest.

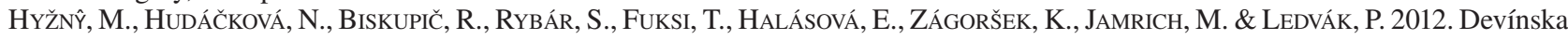
Kobyla - a window into the Middle Miocene shallow-water marine environments of the Central Paratethys (Vienna Basin, Slovakia). - Acta Geologica Slovaca 4, 95-111. 
JÁMBOR Á. 1980: A Dunántúli-középhegység pannóniai képződményei (Pannonian in the Transdanubian Central Mountains). - Annals of the Geological Institute of Hungary 62, 243 p.

JÁMBOR Á., KorPÁsné Hódi M., SzÉLEs M. \& SÜTŐNÉ SzENTAI M. 1987: A kunsági (Pannóniai s. str.) emelet magyarországi fáciessztratotípusának jellemzése [Description of the faciesstratotype of the Kunság (Pannonian s. str.) stage in Hungary]. - Annals of the Geological Institute of Hungary 69/1,37-93.

KaZÁR E., Kordos L. \& Szónoky M. 2007: Danitz-puszta. In: PÁlfy J. \& PAZOnyi P. (szerk.): Óslénytani kirándulások Magyarországon és Erdélyben (Palaeontological excursions in Hungary and Transylvania). - Hantken Press, Budapest, 131-132.

KLEB B. 1973: A mecseki pannon földtana (Geologie des Pannons im Mecsek). - Annals of the Geological Institute of Hungary 63/3, 750-943.

KóKAY J., HÁMOR T., LANTOS M. \& MÜLLER P. 1991: A Berhida 3. sz. fúrás paleomágneses és földtani vizsgálata (The paleomagnetic and geological study of borehole section Berhida 3). - Annual Report of the Geological Institute of Hungary on 1989, 45-63.

KONRÁD Gy. \& SEBE K. 2010: Fiatal tektonikai jelenségek új észlelései a Nyugati-Mecsekben és környezetében (New Records of Young Tectonic Phenomena in the Western Mecsek Mts. and their Surroundings). - Földtani Közlöny 140/2, 445-468.

KonRÁd Gy., Kordos L. \& Sebe K. 2010: Danitz-pusztai homokbánya, Pécs, Mecsek. Őslényvadászat a Pannon-tó peremén. (Danitzpuszta sandpit, Pécs, Mecsek Mts. Fossil hunting along the shores of Lake Pannon.) - In: HaAs J. (ed.): A múlt ösvényein (On trails of the past). Hungarian Geological Society, Budapest, 160-164.

Kovačić, M., Marković, F., Ćorić, S., Pezelj, Đ., Vrsaljko, D., Bakrač, K., Hajek-Tadesse, V., Ritossa, A. \& Tarnaj, I. 2017: Stop 4 Vranović. Disintegration of the Central Paratethys and origin of the Lake Pannon. - In: KovAČÍc, M., WACHA, L. \& HoRvAT, M. (eds): Neogene of the Paratethyan region. 7th International Workshop on the Neogene from the Central and South-Eastern Europe. RCMNS Interim Colloquium. Field trip guidebook. Croatian Geological Society, Zagreb, 22-25.

Krizmanić, K., Sebe K. \& Magyar I. 2021: Dinoflagellate cysts from the Pannonian (late Miocene) “white marls” in Pécs-Danitzpuszta, southern Hungary. - Földtani Közlöny 151/3, 267-274.

MAGYAR I. 2010: A Pannon-medence ósföldrajza és környezeti viszonyai a késó miocénben (Paleogeography and environmental conditions of the Pannonian Basin in the Late Miocene). GeoLitera, Szeged, 140 p.

Magyar, I., Geary, D. H. \& Müller, P. 1999. Paleogeographic evolution of the Late Miocene Lake Pannon in Central Europe. - Palaeogeography, Palaeoclimatology, Palaeoecology 147/3, 151-167. https://doi.org/10.1016/S0031-0182(98)00155-2

MagYar I., JuHÁsz Gy., Szuromi-Korecz A. \& SüTő-SzEnTAI M. 2004: A pannóniai Tótkomlósi Mészmárga Tagozat kifejlődése és kora a Battonya-pusztaföldvári-hátság környezetében (The Tótkomlós Calcareous Marl Member of the Lake Pannon sedimentary sequence in the Battonya-Pusztaföldvár region, SE Hungary). - Földtani Közlöny 133, 521-540.

Magyar, I., CZiczer, I., Sztanó, O., DÁvid, Á. \& Johnson, M. 2016: Palaeobiology, palaeoecology and stratigraphic significance of the Late Miocene cockle Lymnocardium soproniense from Lake Pannon. - Geologica Carpathica 67/6, 561-571. https://doi.org/ 10.1515/geoca-2016-0035

SEBE K. 2021: Structural features in the Miocene sediments of the Pécs-Danitzpuszta sand pit

Sebe, K., Csillag, G., Dulai, A., Gasparik, M., Magyar, I., Selmeczi, I., Szabó, M., Sztanó, O. \& Szuromi-Korecz, A. 2015 : Neogene stratigraphy in the Mecsek region. In: BARTHA, I-R., KRIVÁN, Á., MagYAR, I., SeBE, K. (eds.): Neogene of the Paratethyan Region. 6th Workshop on the Neogene of Central and South-Eastern Europe. An RCMNS Interim Colloquium. Programme, Abstracts, Field Trip Guidebook. 2015.05.31-06.03, Orfü. Hungarian Geological Society, Budapest, 102-124.

Sebe, K., Konrád, Gy., Harangi-Lukács, R., Harangi, Sz., Benkó, Zs., Pécskay, Z., Magyar, I., Dunkl, I., Sztanó, O. \& Józsa, S. 2016: Linking bio- and chronostratigraphy in Lake Pannon: pyroclastics and biozones in the southwestern Pannonian Basin. - In: Mandic, O., Ppavelić, D., Hrvatović, H., Kovačić, M., Andrić, N. \& SAnt, K. (eds): Program \& Abstracts. Lake - Basin - Evolution, RCMNS Interim Colloquium 2016 \& Croatian Geological Society Limnogeology Workshop, 20-24 May 2016, Zagreb, Croatia. 4344. Croatian Geological Society.

Sebe, K., Kovačić, M., Magyar, I., Krizmanić, K., Špelić, M., Bigunac, D., Sütő-Szentai, M., Kovács, Á., Szuromi-Korecz, A., Bakrač, K., Hajek-Tadesse, V., Troskot-Čorbić, T. \& Sztanó, O. 2020: Correlation of upper Miocene-Pliocene Lake Pannon deposits across the Drava Basin, Croatia and Hungary. - Geologia Croatica 73/3, 177-195., https://doi.org/10.4154/gc.2020.12

Szabó, M., Kocsis, L., Bosnakoff, M. \& SEbe, K. 2021. A diverse Miocene fish assemblage (Chondrichthyes and Osteichthyes) from the Pécs-Danitzpuszta sand pit (Mecsek Mts., Hungary). - Földtani Közlöny 151/4, 363-410.

Szentesi, Z., Sebe, K. \& SzABÓ, M. 2020: Giant salamander from the Miocene of the Mecsek mountains (Pécs Danitzpuszta, southwestern Hungary). - Paläontologische Zeitschrift 94, 353-366., https://doi.org/10.1007/s12542-019-00499-2

Sztanó O., Magyari Á. \& Tóth P. 2010: Gilbert-típusú delta a pannóniai Kállai Kavics Tapolca környéki előfordulásaiban [Gilbert-type delta in the Pannonian Kálla Gravel near Tapolca, Hungary]. - Földtani közlöny 140/2, 167-182.

Szuromi-Korecz, A., Csoma, V., Tóth, E., Sebe, K., Magyar, I., Sztanó, O., BuczKó, K. \& Botka, D. 2021: Various marginal marine environments in the Central Paratethys: Late Badenian and Sarmatian (middle Miocene) marine and non-marine microfossils from Pécs-Danitzpuszta, southern Hungary. - Földtani Közlöny 151/3, 275-304.

ter Borgh, M., Vasiliev, I., Stoica, M., Knezević, S., Matenco, L., Krijgsman, W., Rundić, L. \& Cloething, S. 2013: The isolation of the Pannonian basin (Central Paratethys): New constraints from magnetostratigraphy and biostratigraphy. - Global and Planetary Change 103, 99-118. https://doi.org/10.1016/j.gloplacha.2012.10.001

Tóth P., SzAfí́n P. \& SzTANó O. 2010: Egy pannóniai korú Gilbert-delta felépítése „3D” földradar (GPR) szelvények alapján (Threedimensional GPR imaging of a Gilbert-type delta: a case study from the Late Miocene Lake Pannon, Hungary). - Földtani Közlöny 140/3, 235-250.

VADÁSz E. 1960: Magyarország földtana (Geology of Hungary). - Akadémiai Kiadó, Budapest, 646 p.

Manuscript received: 05/08/2021 